\title{
Quaternary transfer faulting in the Taiwan Foothills: evidence from a multisource approach
}

\author{
B. Deffontaines ${ }^{\text {a,* }}{ }^{\text {, O. Lacombe }}{ }^{\text {a }}$, J. Angelier ${ }^{\text {a }}$, H.T. Chu ${ }^{\text {b }}$, F. Mouthereau ${ }^{\text {a }}$, C.T. Lee ${ }^{\text {c }}$, \\ J. Deramond ${ }^{\text {d }}$, J.F. Lee ${ }^{b}$, M.S. Yu ${ }^{b}$, P.M. Liew ${ }^{\mathrm{e}}$ \\ a Département de Géotectonique, URA-CNRS 1759, Université Pierre et Marie Curie, T. 26, E1, Case 129, 4 Place Jussieu, F-75252, \\ Paris, Cedex 05, France \\ ${ }^{b}$ Central Geological Survey, MOEA, PO Box 968 , Taipei, Taiwan \\ ${ }^{c}$ National Central University, Institute of Applied Geology, Chungli, Taiwan \\ ${ }^{d}$ Laboratoire de Géologie Structurale et Tectonophysique, Université Paul Sabatier, 38, rue des 36 Ponts, F-31400, Toulouse, France \\ ${ }^{e}$ Geological Department, National Taiwan University, 245 Choushan Road, Taipei, Taiwan
}

Received 12 February 1996; accepted 30 July 1996

\begin{abstract}
The major structures of the Western Foothills of Taiwan mainly consist of NNE-SSW-trending folds and imbricated west-vergent thrust systems. The additional occurrence of $\mathrm{N} 140^{\circ} \mathrm{E}$-striking oblique structures was revealed through a multisource approach involving a Digital Elevation Model (DEM), a study of drainage network anomalies, aerial photographs, Side-Looking Airborne Radar (SLAR) images and SPOT-P and Landsat images. These structures are described from north to south based on new field analyses (including stratigraphy and tectonics studies). They are also compared to seismic data and geodetic reconstruction, in order to evaluate their present-day activity. These N $140^{\circ} \mathrm{E}$ major morphostructures are interpreted as left-lateral transfer fault zones, either inherited from the Eurasian passive margin and/or newly formed in the cover in response to the presence of basement highs within the foreland basin (Peikang and Kuanyin highs). The Sanyi and the Chishan transfer fault zones display a high seismic activity; the distribution of earthquakes and the related focal mechanisms confirm the left-lateral movement along $\mathrm{N} 140^{\circ} \mathrm{E}$ directions. The Chiayi, Chishan, and Fengshan fault zones act presently as transfer fault zones, as indicated by GPS data. The associated $\mathrm{N} 70^{\circ} \mathrm{E}$ - to $\mathrm{N} 100^{\circ} \mathrm{E}$-trending faults result from the reactivation of normal faults of the Eurasian passive margin as right-lateral strike-slip faults in the Foothills during the Plio-Quaternary collision in Taiwan. We conclude that multisource and multiscale geomorphic studies combined with tectonic analysis in the field yield a significant contribution to the understanding of the structural and kinematic development of the Western Foothills at the front of the Taiwan collision belt.
\end{abstract}

Keywords: neotectonics; transfer fault zone; fold-and-thrust belt; Digital Elevation Model; drainage network; SPOT-P.; SLAR; palaeostress; Western Foothills, Taiwan

\section{Introduction}

Taiwan is located along a segment of the convergent boundary between the Philippine Sea and

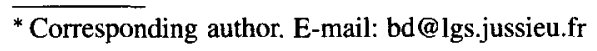

Eurasian plates (e.g., Suppe, 1981; Barrier, 1985; Ho, 1986a,b, 1988; Angelier et al., 1986, 1990; Teng, 1990) (Fig. 1). Northeast of Taiwan, the Philippine Sea plate is subducting to the northwest beneath the Eurasian continental margin, whereas south of Taiwan the South China Sea floor, belonging to the 


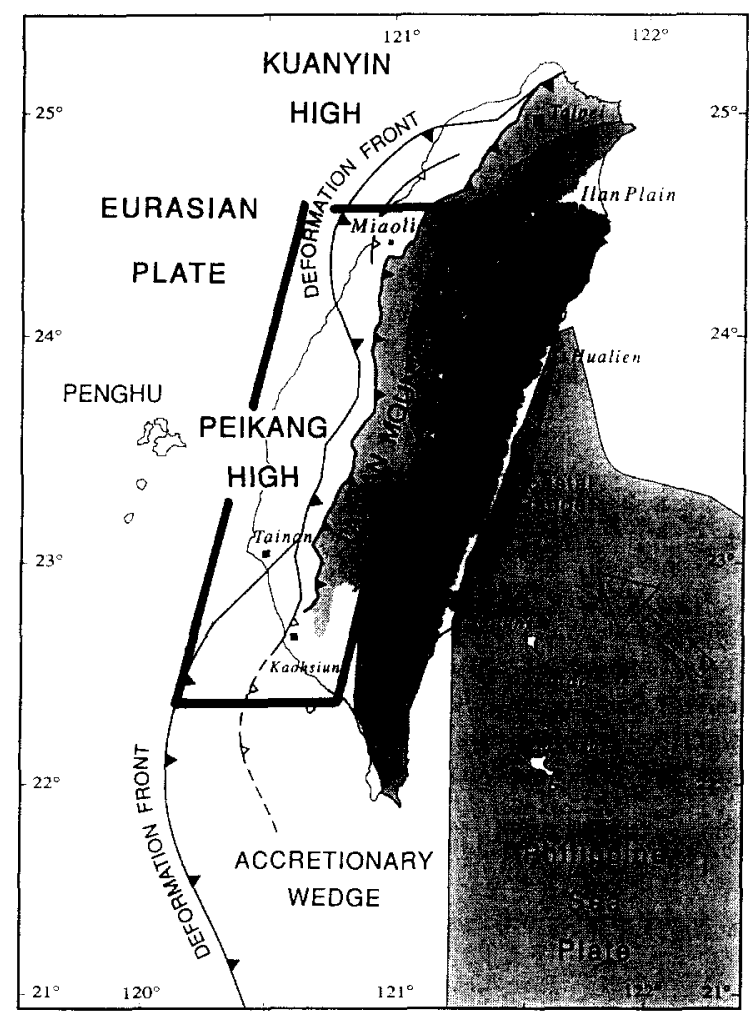

Fig. 1. Geodynamic framework and main structural units of Taiwan. White pattern: Coastal Plain. The frame indicates the investigated area, i.e.. the Western Foothills and the Coastal Plain. Heavy lines indicate major thrusts, triangles on upthrown side. $L . V .=$ Longitudinal Valley.

Eurasia plate, is subducting to the southeast beneath the Philippine Sea plate. Between these major arc-trench systems (Ryukyu and Luzon-Manila, respectively), where active subduction occurs, oblique collision dominates across the Taiwan segment of the plate boundary (Suppe, 1981, 1984). The orogen developed in Taiwan during the late Cenozoic, mainly since $5 \mathrm{Ma}$ (Ho, 1986a,b), is consequent to this active collision.

In this paper, we study the westernmost units of the collision belt, which correspond to two main geological domains: (1) the Western Foothills, composed of non-metamorphic shallow-marine to shelf clastic sediments, Miocene to Pleistocene in age, affected by NW-vergent folds and thrusts, and (2) the Western Coastal Plain, which represents a foredeep basin filled by clastic sediments bounding the undeformed Chinese continental passive margin.
The Western Foothills of Taiwan are structurally and sedimentologically well known because of studies carried out by the Chinese Petroleum Corporation [hereafter CPC; e.g., Geological Maps of Taiwan: Miaoli, CPC (1974), Taichung, CPC (1982)]. The Foothills display active asymmetric folds and low-angle thrust faults, which affect the late Cenozoic continental deposits of the Toukoshan formation (mainly composed of conglomerates and sandstones). The overall magnitude of the deformation decreases from east, where tight folds and steeply dipping thrusts are numerous, to west, where genthe and open folds dominate (Ho, 1986a,b). Fold axes trend mainly $\mathrm{N} 20^{\circ} \mathrm{E}$ and have steep to overturned western flanks commonly cut by WNWvergent thrust faults. The two major décollement levels correspond to the Wuchihshan formation of the Late Oligocene and the Nanchuang formation of the Late Miocene (Suppe, 1976). Minor ones also exist within the Pliocene strata (Ho, 1979. 1986a.b).

Some authors (Ho, 1979, 1986a,b; Pelletier and Stephan, 1986) have suggested the occurrence of oblique structures within the Taiwan Foothills. The development of strike-slip faults, oblique at large angle to the belt trend, often in conjugate sets, was observed but was restricted to some areas of the fold-and-thrust belt (Ho, 1988). These features correspond to the Alishan area and the Shantzechiao-Chingshuikeng area in northern Taiwan (Ho, 1967). Two sets of strike-slip fault zones were evidenced based on displacement of topographic and stratigraphic units: (1) WNW to $\mathrm{E}-\mathrm{W}$ right-lateral strike-slip faults (Biq, 1989), and (2) NNE to N-S left lateral strike-slip faults (Ho, 1979. 1988; Yeh and Yang, 1992). In a previous paper (Deffontaines et al., 1994), a multisource geomorphic analysis at the scale of the whole orogen emphasized the overall presence of oblique features within the Taiwan Foothills, but the tectonic significance of these features was not discussed in detail.

In this paper, we do not discuss this geomorphic analysis of Taiwan again; we rather focus on the front zone of the fold-and-thrust belt and we aim at presenting a new accurate mapping of the Foothills structures, based on subsurface data (e.g., Sun, 1963, 1964), new remote sensing images (SPOT Panchromatic), high-resolution digital eleva- 
tion models, SLAR photographs, aerial photographs and local additional field work, which confirms the presence of structures trending mainly $N 140^{\circ} \mathrm{E}$, oblique to the fold-and-thrust belt. Our purpose is also to demonstrate that these $\mathrm{N} 140^{\circ} \mathrm{E}$-trending structures correspond to transfer faults, that is to strike-slip faults parallel to the thrust transport direction which separate two parts of a given thrust sheet, each of which may have different displacements and deformations (McClay, 1992). We finally aim at discussing the significance of these transfer faults in the framework of the westward propagation of thrust units onto the Chinese passive margin, in response to its ongoing collision with the Luzon arc.

It is first necessary to focus on the structure of the Western Foothills and the Coastal Plain structures, in order to provide new evidence for major $\mathrm{N} 140^{\circ}$ E-trending structures oblique to the active deformation front. We aim at locating precisely these structures and at defining their mechanisms during the Quaternary, based on geomorphic as well as structural and (palaeo)stress data. There is no need to discuss again both the geodynamic context and the general structure of Taiwan, which are summarized in Fig. 1 and discussed in other papers of this special issue.

\section{Insights from numerical geomorphic approach and remote sensing analysis}

\subsection{The Digital Elevation Model (DEM) and its derivatives}

We obtained local digital elevation models by digitizing isocontours of topographic maps of the Western Foothills of Taiwan (Fig. 2A), and using stereoscopic aerial photographs or spatial images. The DEM ground resolution is $50 \times 50 \mathrm{~m}$. Minor artefacts appear on DEM, mainly because of both the limits of the splin bicubic interpolation in the areas, and local alteration of topographic data (large buildings).

In order to recognize the major morphological features, we examined additional information obtained through the analysis of parameters derived by numerical means (such as slopes or hill-shading maps; see Deffontaines et al., 1994 for examples).
Computer programs (Carvalho, 1995) provided numerical morpho-tectonic and graphic outputs, such as for different simulated hill-shading pictures. It gives a good bird's-eye view of the structure and reveals the major geomorphic discontinuities (Fig. 2B).

To analyze and interpret these documents (Fig. 2B), we used a lineament analysis based on structure, texture, shape, and colour (intensity hue and saturation: O'Leary et al., 1976; Scanvic, 1983), which correspond to qualitative interpretation criteria in remote sensing. Especially, alignments characterized by similar pixel values (colours) indicate lithological or structural linear features.

In the DEM-derived maps, linear features striking obliquely or perpendicularly to the major structural trends were recognized, with smaller length and lesser continuity than for the well known major features (Fig. 2B). For instance, linear features trending NW-SE are clearly visible in the southern segments of the Pakuashan anticline (Fig. 2A, B). Where lithological contrasts are absent and thus cannot account for differential erosion, which is the most common case, these oblique and transverse features are tectonically significant. In contrast to longitudinal structures, many of these oblique features were not shown in the geological map of Taiwan (Ho, 1986a,b) and they are even absent in more detailed local maps. Furthermore, local geological studies in the field resulted in identification of major and minor fracture sets along such oblique trends, at various sites in the Western Foothills. The identification of strike-slip movements along the major fault lines, and in several cases the identification of linear features themselves as major fractures, are generally impossible to obtain from the DEM analysis solely. We point out, however, that despite this lack of direct evidence their existence is ascertained by the association of morphological studies and local analyses of fracture and fault patterns.

\subsection{Drainage pattern and anomalies analysis}

The Western Foothills drainage pattern (Fig. 2C) was simply extracted manually from topographic maps of scale 1:100,000. In these maps, the drainage pattern is accurately described where all streams, including small dry talwegs, could be mapped. The regional drainage pattern of the stud- 


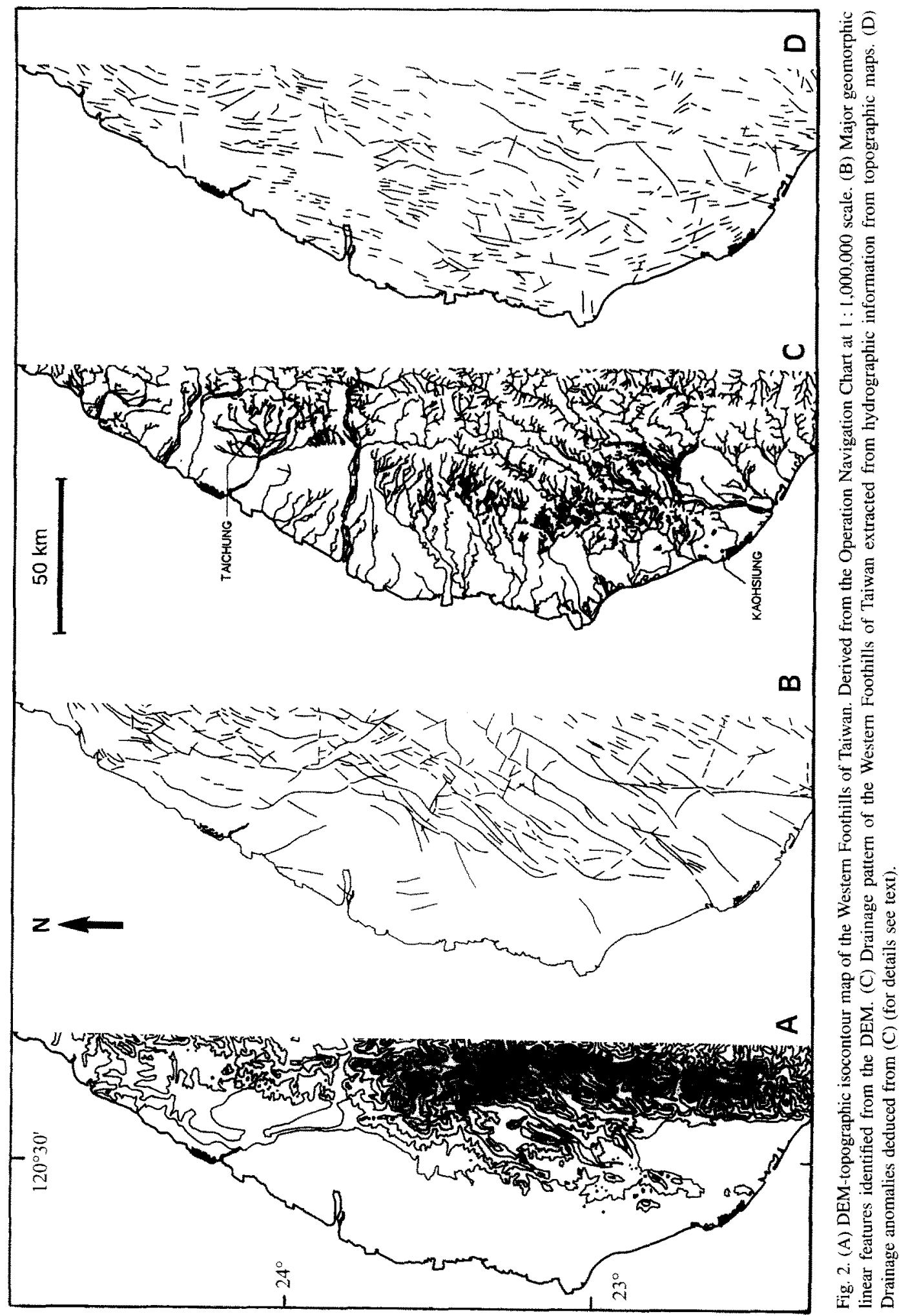


ied area identified in the map of Fig. $2 \mathrm{C}$ belongs to different basic drainage pattern types, which have been defined based on various studies that resulted in a descriptive drainage classification (Howard, 1967; Deffontaines and Chorowicz, 1991). This classification is based on considering parameters such as the confluence angle of tributaries, drainage symmetry, drainage frequency (number of streams per unit area), and drainage density (length of streams per unit area). Using this classification, one thus distinguish from north to south and from west to east, the parallel drainage of the Coastal Plain (mainly along W-E trends) and the spectacular development of a dendritic drainage pattern displaying a high stream frequency in the Western Foothills (Fig. 2C).

In any preliminary interpretation based on the identification of these types of drainage patterns, differences in lithology should be carefully considered. For instance, the southeastern portion of the Coastal Plain and Western Foothills is characterized by strong changes in drainage frequency and density partly related to lithology, e.g., the systematic occurrence of mudstones. The relationship between the type of drainage pattern and neotectonic deformation is complex, due to interactions between (1) lithology and structure, (2) climatic and erosional factors, and (3) uplift and shortening.

Drainage network anomalies (Hobbs, 1904; Howard, 1967; Deffontaines and Chorowicz, 1991; Deffontaines et al., 1992, 1994) are revealed using channel patterns and their local modifications. Fig. 2D represents the Foothills drainage anomalies which have been extracted manually from the following criteria: (1) local modifications of the drainage pattern: radial, centripetal (negative) or centrifugal (positive), annular or parallel when it should be dendritic if not influenced, for instance within the Western Coastal Plain (Howard, 1967; Deffontaines and Chorowicz, 1991); (2) local modifications of the channel pattern such as rectilinear, curvilinear, or compressed meanders and oriented distribution of marshes, lakes, ponds, and aquatic vegetation; (3) modification of the confluence angle; e.g., streams usually converge at a $60^{\circ}$ confluence angle, locally it can be as large as $120^{\circ}$ when associated with meanders, indicating a depressed zone in the alluvial plain (e.g., the Coastal Plain); (4) divergence of streams which indicates raised zones, or domes; (5) align- ment of high-angle curves, confluences, springs, and tributaries; (6) symmetry of tributaries (the Coastal Plain); (7) flow directions reverse or oblique to the shoreline; and (8) low or high frequencies of streams (numbers per unit area) provide evidence for drainage anomalies (e.g., the southern part of the Coastal Plain).

Drainage anomalies are widely distributed through the studied area (Fig. 2D). Their analyses are useful in the areas where geological field-work is difficult. This is the case for the flat lowlands of the Coastal Plain due to extreme anthropic activity (rice fields) and where few outcrops are available.

To conclude, the drainage anomaly analyses reveal the presence of oblique structures within the flat lowlands which present vertical and horizontal displacement determined by using morphological markers such as anomalous rectilinear drainage.

\subsection{Aerial photographs analysis}

High-scale analyses of aerial photographs (scale $1: 17,000$ ) were undertaken at different places and in different ways, depending on the neotectonic problems addressed (e.g., the Miaoli, Sanyi, Pakuashan, Chiayi and Chishan areas). These analyses allowed accurate identification and precise geological mapping of the morphostructures oblique to the deformation front. They cannot be extensively discussed herein; however, their contribution to a comprehensive morphotectonic analysis must be pointed out, and such analyses will be taken into account in order to build a complete and accurate morphoneotectonic sketch map of the Western Foothills. We point out that from the point of view of tectonic analysis, the detail displayed in aerial photographs is an information accurate enough to be directly and systematically correlated with the results of tectonic observation in the field. In contrast, analyses of other images with poorer resolution (e.g., SPOT and SLAR images) reveal features which are of interest but in many cases cannot be directly correlated with structures observed in outcrops.

\subsection{Side-looking airborne radar (SLAR) analysis}

On SLAR photographs, relief and texture are emphasized because the radar radiometry enhanced 


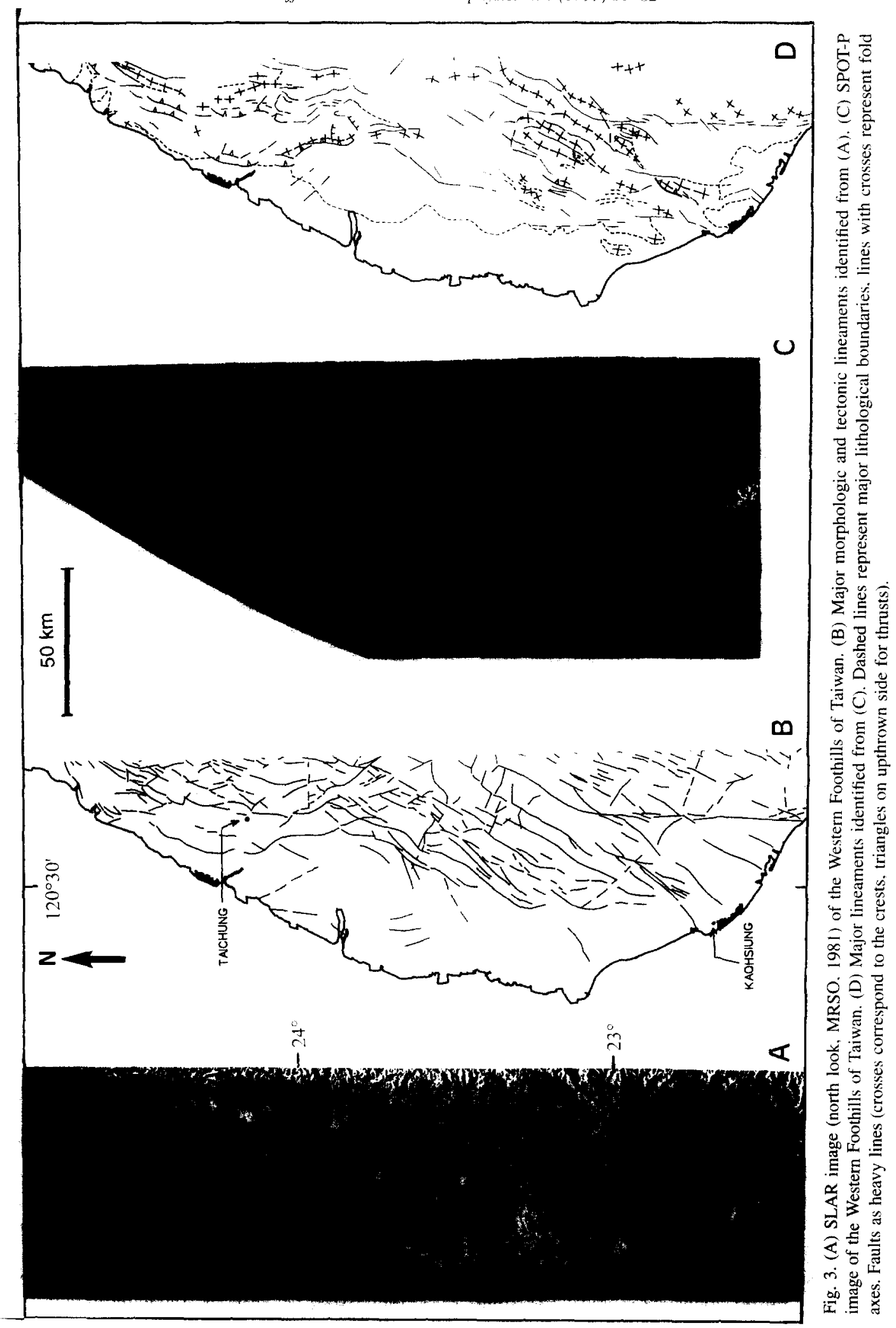


slope effects. Despite the inherent anisotropy of radar radiometry in such rough relief, there are few artifacts due to the small geometric distortions because of the high value of the incidence angle. Both the north and south looks of the SLAR imagery were first analyzed (Deffontaines et al., 1994) as a whole. Here, we focus on the structure of the Taiwan Western Foothills, in order to highlight the structures trending obliquely to the deformation front structures (Fig. 3A).

The SLAR interpretation map (Fig. 3B) shows the location of faults, Quaternary deposits, antiforms and synforms and lithological traces. Note (1) the large number of features parallel to the structural grain of the Western Foothills, which correspond to well-known faults and folds, (2) the more interesting presence of oblique NW-SE trends (e.g., southwest of Taichung, the Pakuashan area interpreted below as a transfer zone across the Foothills and the outer Central Range). The SLAR image appears to be a major source of data despite its intrinsic distortion; it is of special interest as far as the geological structure is concerned. Furthermore, because of its accuracy, it provides a good complement of DEMs previously mentioned.

\subsection{SPOT image analysis}

Four high-resolution SPOT Panchromatic scenes $(10 \times 10 \mathrm{~m}$ ground resolution) of western Taiwan (KJ: 299/301-4, 1987-8) have been acquired, processed, and analyzed (Fig. 3C). Focusing on the Western Foothills (from Miaoli to the north, down to Kaohsiung to the south), the SPOT images allow a morphostructural overview (with much less distortion than SLAR images and better accuracy). This analysis allows improvement of the structural information already existing in geological maps (Hsu, 1956; Ho, 1986a,b). SPOT-P images reveal NE-SWtrending crests which correspond to anticlines and associated thrusts and NW-SE oblique structures in the Western Foothills (Fig. 3C, D). Note that the interpretation of spatial and aerial data not only allowed mapping of linear features of the Western Foothills (oblique structures), but also provided new data within the interfluvial (e.g., in summits, saddles, and flanks of the topography), which were not obtained from the previous drainage analyses.

\section{Insights from tectonic and seismic analyses}

\subsection{Seismic distribution in the Western Foothills}

The distribution of epicentres of shallow earthquakes (less than $17 \mathrm{~km}$ deep) in the Western Foothills for the year 1992 (Shin and Chang, 1992) provides evidence for a lack of seismic activity in two subdomains (I and II in Fig. 4A). The northern subdomain corresponds to the Peikang High area. It is clearly bounded by a $\mathrm{N} 140^{\circ}$ structural trend to the north and a $N 080^{\circ}$ one to the south, each of them separating areas of highly contrasting seismic activities. A southern subdomain corresponds to the Kaohsiung area; its northern boundary also highlights a $\mathrm{N} 140^{\circ}$ structural trend. Note also the densely distributed seismic epicentres between these two domains (Fig. 4A) which correspond to large earthquakes related to thrusting and strike-slip faulting. It is interesting to observe that these structural trends display the same orientation than the $\mathrm{N} 140^{\circ} \mathrm{E}$ trends previously identified from independent geomorphic analyses. As an example, the $\mathrm{N} 140^{\circ} \mathrm{E}$-trending Sanyi and the Chishan fault zones (see below) thus appear as major seismic boundaries.

\subsection{Plio-Quaternary and present-day stress pattern in the Western Foothills and relation to fault kinematics}

Motion along the $\mathrm{N} 140^{\circ} \mathrm{E}$ fault zones can be predicted by comparing their orientations to the Quaternary and present-day stresses in western Taiwan derived from focal mechanisms of earthquakes (Yeh et al., 1991), borehole breakouts (Suppe et al., 1985) and Quaternary faulting analyses (Angelier et al., 1986; Chu, 1990; Lacombe et al., 1993a; Lee, 1994). Despite heterogeneous stress distribution in SW Taiwan (Kaohsiung area: Lacombe et al., 1995), the Quaternary/present-day regional stress field mainly corresponds to a $\mathrm{N} 100-110^{\circ}$ compression (Fig. 4B). This $\mathrm{N} 100-110^{\circ}$ compression is likely to induce a left-lateral motion along the $\mathrm{N} 140^{\circ} \mathrm{E}$ fault zones while the $\mathrm{N} 80^{\circ} \mathrm{E}$ faults are right-lateral. As an example, the left-lateral motion is obvious from the swarm of compressional and strike-slip earthquake focal mechanisms north of the northern domain I (Yeh et al., 1991; Shin and Chang, 1992). 


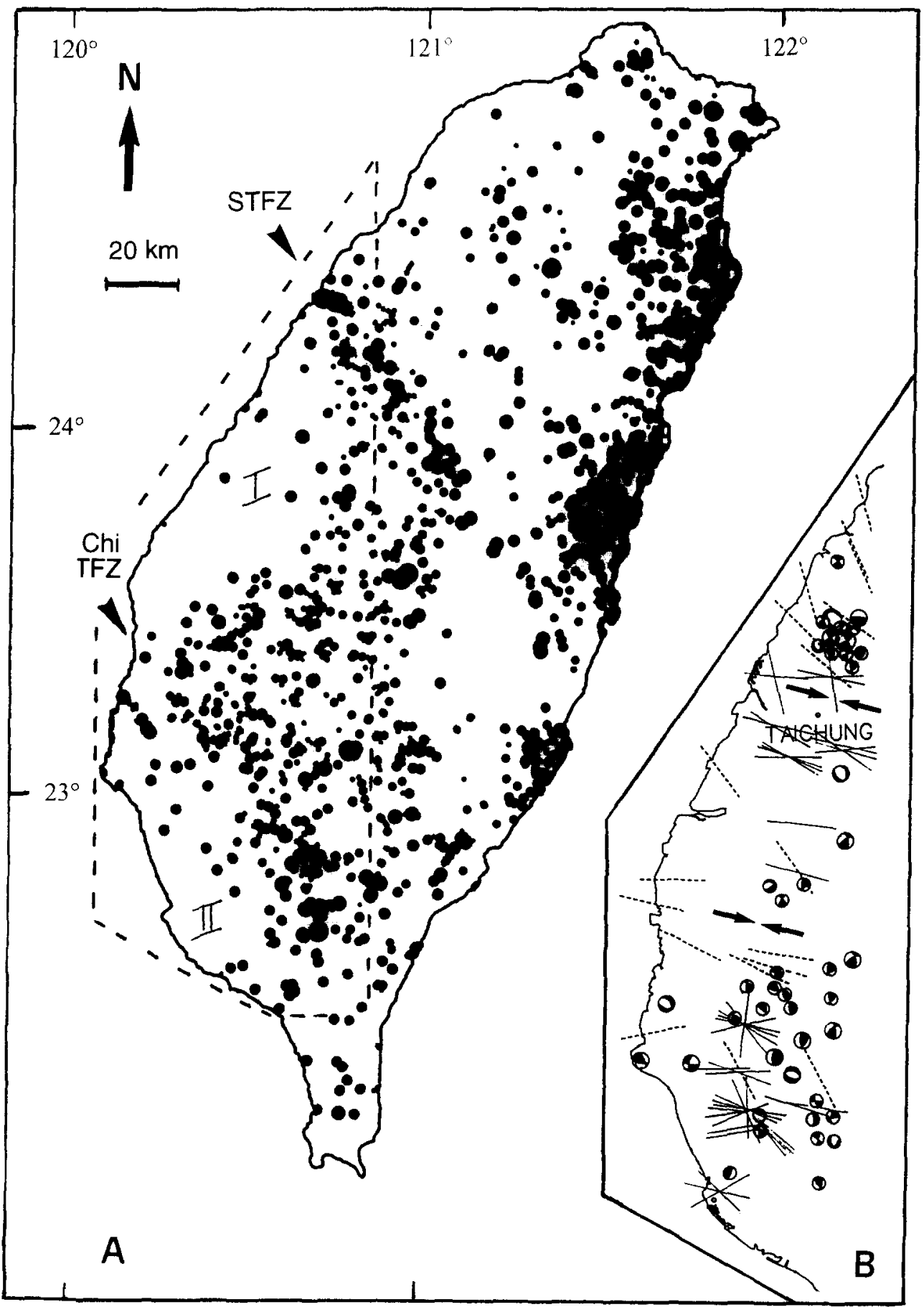

Fig. 4. (A) Distribution of epicentres of shallow earthquakes (Jess than $17 \mathrm{~km}$ deep) in 1992 (from Shin and Chang, 1992). (B) Late Quaternary-present-day crustal stress pattern in the Western Foothills of Taiwan. Earthquakes focal mechanisms after Yeh et al. (1991) and Shin and Chang (1992), white areas indicate quadrants of dilatational first motion. Dashed lines: direction of the maximum horizontal stress derived from borehole breakouts (Suppe et al., 1985). Continuous lines: direction of $\sigma 1$ axes deduced from Quaternary faulting analyses (Angelier et al., 1986; Chu, 1990; Lacombe et al., 1993a; Lee, 1994). Black arrows indicate the average direction of the regional compression. 


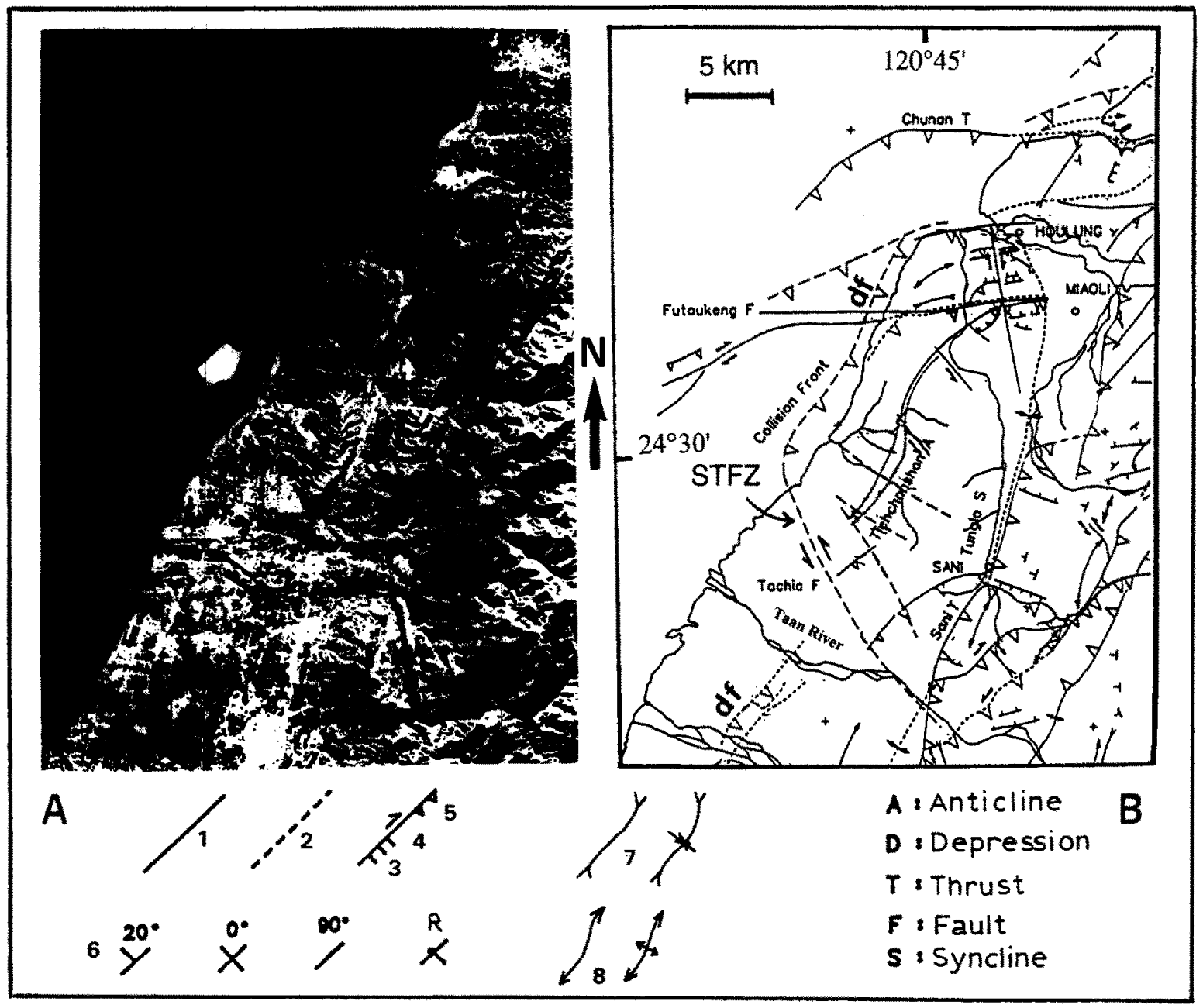

Fig. 5. Sanyi transfer fault zone. (A) SLAR image looking north (MRSO, 1981). (B) Analysis and interpretation of (A). $l=$ major faults with unknown sense of slip; $2=$ inferred faults; $3,4,5=$ faults with normal, strike-slip and reverse sense of slip, respectively; $6=$ dip of bedding $(R=$ reversed); $7=$ syncline; $8=$ anticline; $d f=$ deformation front (equivalent to collision front).

\section{Structural field-work and tectonic analysis of NW-trending morphostructures}

\subsection{Sanyi transfer fault zone (STFZ)}

North of the Sanyi transfer fault zone (hereafter STFZ), the deformation is clearly decreasing toward the west. The western region is characterized by a smooth relief marked by few gentle anticlines (as the Tienhchanshan anticline) and associated thrusts (as the Futoukeng thrust), whereas to the east the area shows large structures like the Chuhuangkeng anticline. The transition between these two areas of contrasting deformation corresponds to the northern branch of the Sanyi thrust and is underlined by the N-S-trending Miaoli depression (Fig. 5).

This northern region greatly differs from the region located south of the Sanyi fault zone where the flat lowlands of the Coastal Plain develop. The radar signature (SLAR of Taiwan, MRSO, 1981, South or North look) illustrates the sinusoidal shape of the deformation front ('collision front') north and south of the Taan River (Fig. 5A). Effectively, north of the STFZ, the deformation front is shifted westward, relative to the southern region (Fig. 5B). One may notice a similar $\mathrm{S}$-shape of the main anticline axes. 
This structural information argues in favour of a major structural trend oriented $\mathrm{N} 140^{\circ}$ along which virgation of structural axes and mismatches of structures occur. The existence of this major structure is independently ascertained by the south termination of the CPC Tiehchanshan oil/gas field (located within the Tiehchanshan anticline north of the STFZ), which is likely to be found further southeast in the Tatushan-Taichung area.

The STFZ is marked by an important amount of seismic events (Fig. 4A). As previously mentioned, the focal mechanisms (Yeh et al., 1991) and the related calculated stress orientations (Fig. 4B) indicate a general left-lateral motion along this transfer fault zone. North of the STFZ, close to the Houlong area, the $\mathrm{N} 80^{\circ} \mathrm{E}$ normal faults related to the extensional deformation of the Chinese passive margin were reactivated close to the deformation front as rightlateral transpressive structures (Huang et al., 1993), and thus may be considered as shear zones conjugate of the major $\mathrm{N} 140^{\circ} \mathrm{E}$ fault zone (Fig. 5B).

The left-lateral motion along the $N 140^{\circ} \mathrm{E}$ fault zone is confirmed by field observations of brittle microstructures. Impressed pebbles, joints and striated microfaults were observed at many places in the conglomerates of the Toukoshan formation. Combined with the results previously obtained by Chu (1990) in this area, we thus characterize a N $110^{\circ}-120^{\circ}$ direction of Quaternary compression. Note that this trend of compression is likely to induce left-lateral motion along the $\mathrm{N} 140^{\circ} \mathrm{E}$ direction of the Sanyi fracture zone. Taking into account both the $\mathrm{N} 140^{\circ} \mathrm{E}$ trend and the location of the STFZ, as well as its high seismic activity, we propose to interpret it as the present-day northern boundary of the Peikang High, undergoing left-lateral shear and reactivating a weakness zone inherited from the extension of the Chinese passive margin (communication of the $\mathrm{CPC}$ ).

\subsection{Pakua transfer fault zone (PTFZ)}

Evidence for transcurrent tectonic features in the Pakuashan-Tatushan area was based on structural observations from SPOT-P, DEM (Fig. 6A, B) and field-work. The most striking feature is the virgation of the axes of the Tatu and Pakua anticlines (Fig. 6B). With respect to the regional $\mathrm{N}-\mathrm{S}$ trend of anticlines, the arcuate (or even sigmoidal) shape of their axes suggests occurrence of a large $\mathrm{N} 140^{\circ} \mathrm{E}$ left-lateral fault zone (Fig. 6B, C). The differential pinching and finally the closing of the Taichung piggy-back basin to the PTFZ (Fig. 6C) associated with the guidance of the Tatu River (Fig. 6B) also indicate a major $\mathrm{N} 140^{\circ} \mathrm{E}$ structural trend.

Other evidence of a major $\mathrm{N} 140^{\circ} \mathrm{E}$ trend (associated with second-order $\mathrm{N} 080^{\circ} \mathrm{E}$ trends) is given by drainage anomalies and offset of major structures deduced from remote sensing analysis (SPOT-P and SLAR). The analysis of drainage anomalies reveals drainages oblique to the dip-slope which underline conjugate $\mathrm{N} 080^{\circ} \mathrm{E}$ and $\mathrm{N} 140^{\circ} \mathrm{E}$ joints located on the back of the Pakua and Tatu anticlines, as well as structurally guided drainage anomalies trending $\mathrm{N} 140^{\circ} \mathrm{E}$ situated on top of and oblique to the anticline axis (Fig. 6B). In addition, the Chelungpu thrust (east of Taichung) displays minor ( 1 to $2 \mathrm{~km}$ ) left-lateral offsets along $\mathrm{N} 140^{\circ} \mathrm{E}$ faults and right-lateral offsets along $\mathrm{N} 080^{\circ}$ faults. The aerial photographs suggest that the southern Tatushan anticline is bounded by a $\mathrm{N} 140^{\circ} \mathrm{E}$ fault zone (presence of sedimentary dykes, fractures etc.). Tectonic analyses in outcrops are also consistent with the occurrence of a major $\mathrm{N} 140^{\circ}$ wrench fault zone in northern Pakuashan acting as a left-lateral transtensional transfer fault zone: field measurements reveal conjugate sets of $\mathrm{N} 140^{\circ}-150^{\circ}$ left-lateral minor strike-slip faults with $\mathrm{N} 080^{\circ}-090^{\circ}$ right-lateral ones. Some of these left-lateral faults show a normal component of motion, consistent with a $\mathrm{N} 120^{\circ}$ shortening associated with the $\mathrm{N} 030^{\circ}$ extension also indicated by NW-trending normal faults. We thus conclude that a major wrench fault zone occurs in northern Pakuashan (Fig. 6B. C).

\subsection{Chicavi transfer fault zone (CTFZ)}

SLAR image analysis (Fig. 7A) complemented by recent field work allowed accurate structural mapping of the Chiayi area (Fig. 7B). The Chiayi transfer fault zone (CTFZ) is revealed by (1) the lateral displacements of the apparent deformation front revealed by the strongly eroded relief on the SLAR image (the deformation front is further west. north of the CTFZ, see white arrow Fig. 7A); (2) the differential location of the frontal conglomerates (further west, north of the CTFZ, see the heavy line, Fig. 7B); (3) the virgation of the Chukou thrust fault 


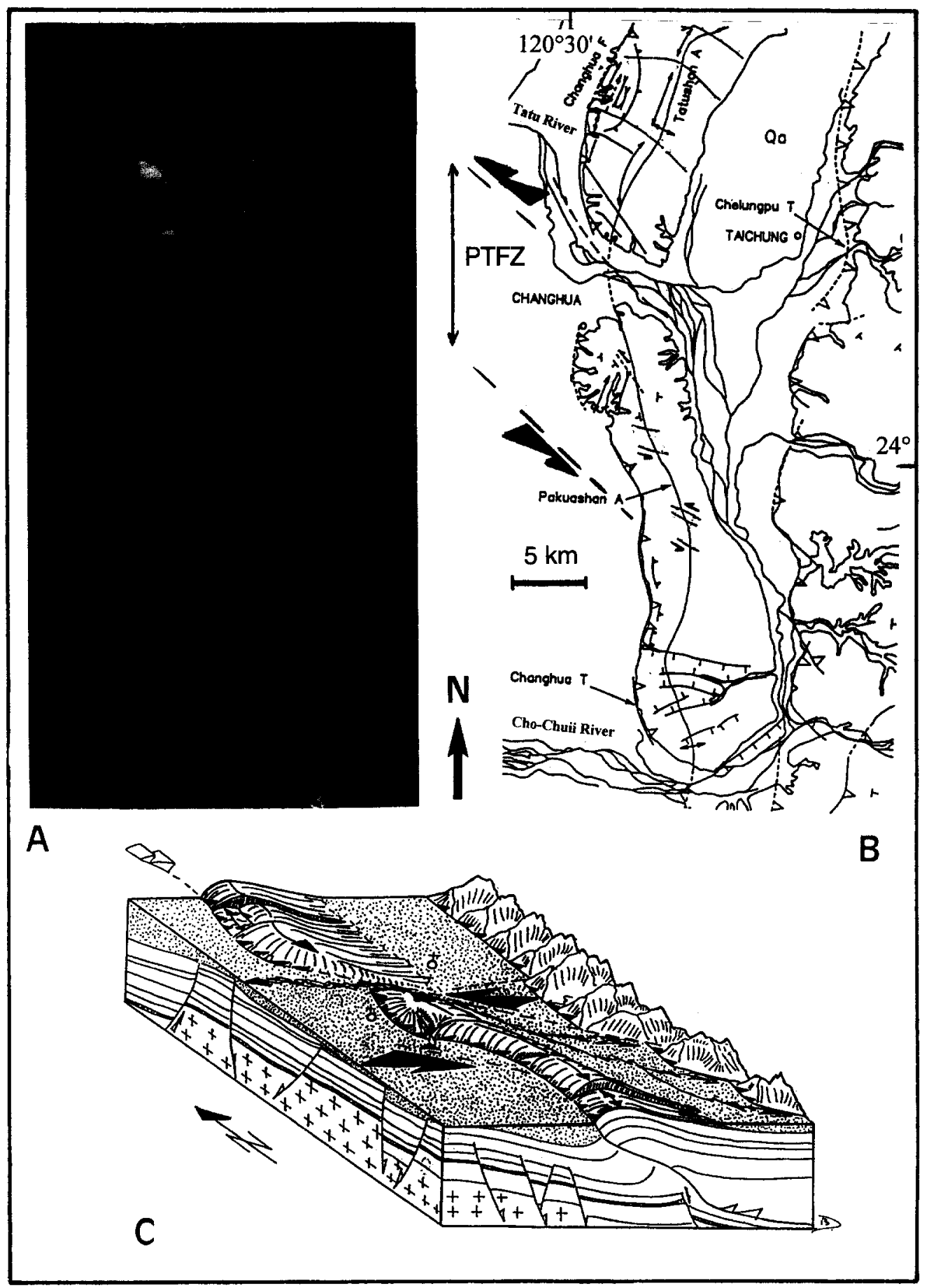

Fig. 6. Pakua transfer fault zone. (A) SPOT panchromatic image of Pakuashan area: note that the dark colour corresponds to the flanks covered by high tropical vegetation, while the grey and white colours correspond to rice crops and habitations. Note the oblique drainage of the major river, the pinching of the Taichung basin and the sigmoidal shape of Pakuashan area. (B) Analysis and interpretation of (A). Note the E-W faults characterized by a normal component within the folds and the N $140^{\circ} \mathrm{E}$ major trend of the transfer fault zone (PTFZ). Same key as in Fig. 5. (C) 3-D schematic view of the Pakuashan area ( $C=$ Changhua; $T=$ Taichung). 


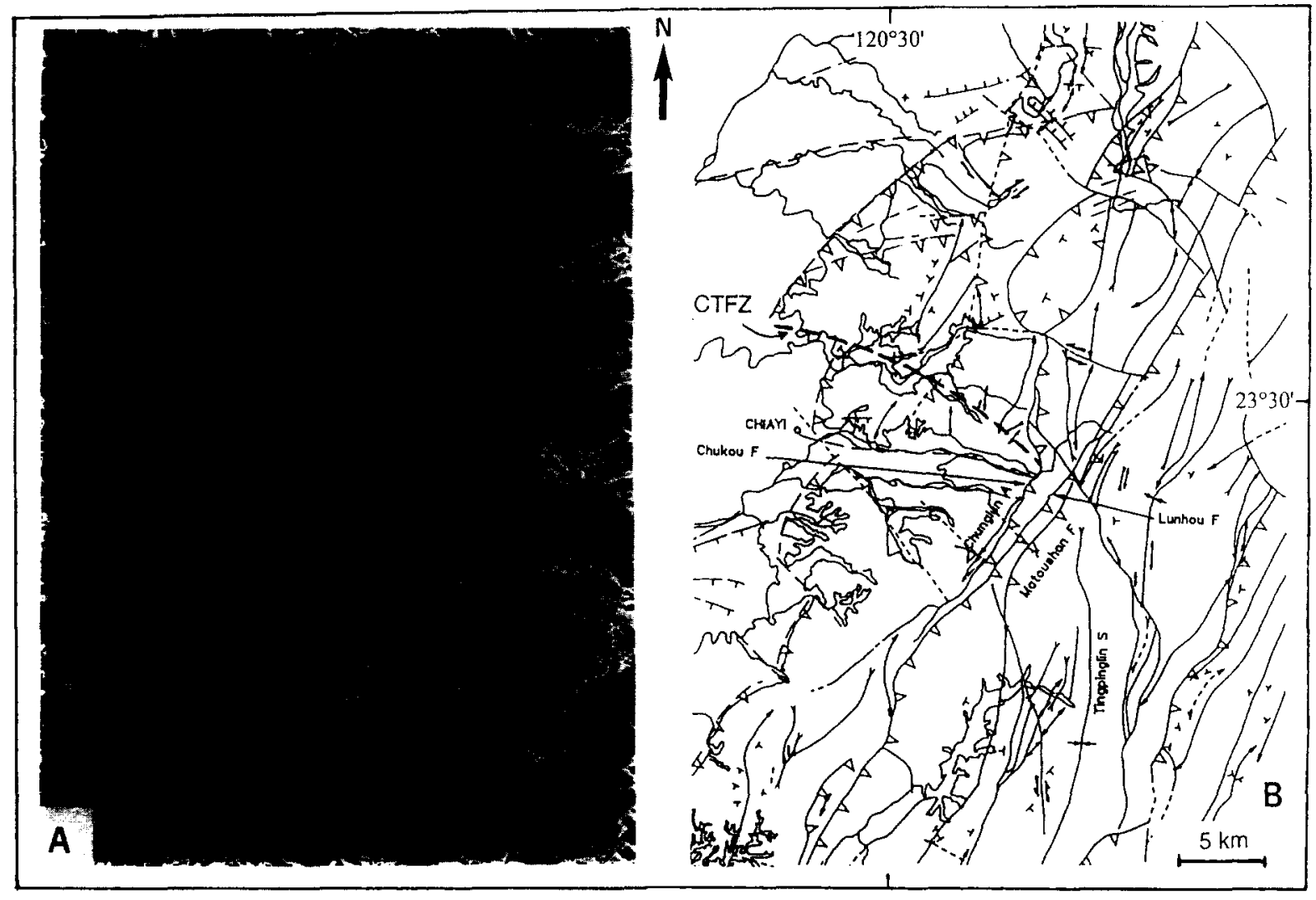

Fig. 7. Chiayi transfer fault zone. (A) SLAR image looking north (MRSO, 1981). Note the lateral offset of the deformation front east of Chiayi. (B) Analysis and interpretation of (A). Note the different structures on both part of the Chiayi transfer fault zone. Same key as in Fig. 5.

(NE-trending south to the STFZ while N-S-trending north of it, Fig. 7B); and (4) the different wavelength, amplitude and apparent offset of the anticline axes north and south of the transfer fault zone (Fig. 7B). Note that close to the Chukou fault, E-W-trending faults have already been described as transfer structures (Ho, 1986a,b).

\subsection{Chishan transfer fault zone (ChiTFZ)}

Considering previous mapping of the area south of the Tsengwen River by the CPC, our field work was focused on the Chishan area where the presence of a N130 E-trending strike-slip fault had only been inferred before (Deffontaines et al., 1994), mainly based on the presence of linear features in SLAR photographs and drainage patterns.

In the field, the NW-SE Chishan transfer fault zone principally crops out within an elongated an- ticline, more than $20 \mathrm{~km}$ long and $1 \mathrm{~km}$ wide. This zone contains a major NW-SE strike-slip fractured zone, associated with a variety of normal and reverse components of motion. Most of the movement has been accommodated along several shear zones, where deformation is tightly localized. This deformation is easily seen in the field because it is associated with a spectacular occurrence of highly deformed black clays which appear as black oblique stripes which cut and offset the light-grey mudstones. In detail, these sheets of sheared clay display narrow-spaced shear cleavage and small truncated elements, contrasting with the absence of large deformation in the surrounding mudstones. At the local scale, the passive rotation of markers within these shear bands consistently indicate a left-lateral sense of shear. At a wider scale, the upward divergent geometry of these faults suggests that the whole pattern is a positive 'flower structure', consistent with the 
left-lateral faulting recognized in individual shear zones. The locations of the anticline axes on both sides of the fault zone also support our interpretation of this $\mathrm{N} 140^{\circ}$ structure as a major left-lateral transfer fault zone (ChiTFZ).

Along the Tsengwen River, some outcrops within Plio-Quaternary shales allowed measurements of striated microfaults: left-lateral strike-slip faults striking parallel to the $\mathrm{N} 130^{\circ}$ fault zone are associated with conjugate right-lateral strike-slip faults trending $\mathrm{N} 050^{\circ}-080^{\circ} \mathrm{E}$ (Fig. 8). Based on Angelier's inverse method (Angelier, 1990), we identified a $\mathrm{N} 107^{\circ} \mathrm{E}$ compressional strike-slip stress regime, again consistent with the left-lateral motion along the fault zone.

As for the other transfer fault zones, matching the structures present on both sides of the fault zone is difficult. In some cases, however, we could determine the displacement rate along this fault zone, based on the offset of lithologic markers. A sandstone bed, $0.4-0.5 \mathrm{Ma}$ in age (NN19-NN20 zones) displays a sinistral offset of $6 \mathrm{~km}$. This suggests a minimum slip-rate of at least $12 \pm 4 \mathrm{~mm} /$ year, along the $\mathrm{N} 130^{\circ} \mathrm{E}$-trending fault zone (Mouthereau et al., 1996).

\subsection{Fengshan transfer fault zone (FTFZ)}

The high-resolution DEM (Fig. 9A) reveals the antiforms (interpreted as west-vergent folds) and synforms (back-fold and/or piggy-back basins) of southwestern Taiwan. For instance, the small Tainan antiform (Fig. 9A) corresponds to the new location of the deformation front which is farther northwest than what was commonly admitted (e.g., near Kaohsiung according to Lee et al., 1995). Note that Sun (1964) already described the Tainan anticline marked by the radial centrifugal drainage pattern and the eastern fault (the Houchiali fault, that we consider as a backthrust), but did not interpret it as the signature of the deformation front. The basins are marked by the flat lowlands area and the shoreline indentations behind the folds.

The sigmoidal virgation of the NE-SW-trending Takangshan and Panpingshan anticlines north and south of the FTFZ, visible on the DEM (Fig. 9A), argue in favour of a major $\mathrm{N} 140^{\circ}-150^{\circ} \mathrm{E}$ left-lateral transfer fault zone in this area (Fig. 9B). This transfer fault zone is underlined by the presence of a low longitudinal depression within the FTFZ, evidenced in the DEM (white arrow, Fig. 9A).

The Pleistocene reef limestones covering the asymmetric anticlines of Takangshan and Panpingshan crop out as large lenses interbedded within the poorly consolidated clastic sediments of the Guntingkeng formation. These reef formations developed during the Pleistocene in relation to thrust-related folding (Lacombe et al., 1997). It is useful at this stage to consider the extensive palaeostress analysis carried out in this area, because it is in part probably related to the presence of the transfer fault zone discussed herein. Field observations and tectonic analysis of minor striated faults within these limestones allowed identification of two main directions of compression: a NW-SE compression and an ENE-WSW compression, marked in the field by strike-slip faults and some reverse faults (Fig. 9B). Compared to the homogeneous Quaternary ESEWNW $\left(\mathrm{N}^{\circ} 05^{\circ}\right)$ direction of compression in the whole of the southern Taiwan Foothills (Angelier et al., 1986), the Kaohsiung region thus displays a heterogeneous, disturbed stress field, with two apparently contrasting Pleistocene states of stress. Actual polyphase tectonism being unlikely in Pleistocene series, this heterogeneous stress distribution cannot be consistently explained by two successive tectonic events; it should rather be explained in terms of local perturbations of the regional $\mathrm{N} 105^{\circ} \mathrm{E}$ compression. Because field studies and numerical modelling show that stress deviations occur in the vicinity of major fault zones (e.g., Xiahoan, 1983; Zoback et al., 1987; Lacombe et al., 1993b), we propose that the regional $\mathrm{N} 105^{\circ}$ compression underwent deviation within the complex pattern of thrust-related folds connected by major wrench fault zones of southwestern Taiwan: this deviation resulted in a stress component oriented NW-SE nearly perpendicular to the fold axes and nearly parallel to the main $\mathrm{N} 140^{\circ}-\mathrm{N} 150^{\circ}$-trending Fengshan transfer fault zone and in a ENE-WSW to $\mathrm{E}-\mathrm{W}$ compression oblique at large angle to the $\mathrm{N} 140^{\circ}-\mathrm{N} 150^{\circ}$ wrench fault zones (Lacombe et al., 1997) (Fig. 9B). According to this interpretation, these compressions probably followed each other (or alternated) quickly in the Kaohsiung region during the Pleistocene, both causing a left-lateral displacement along the FTFZ. 


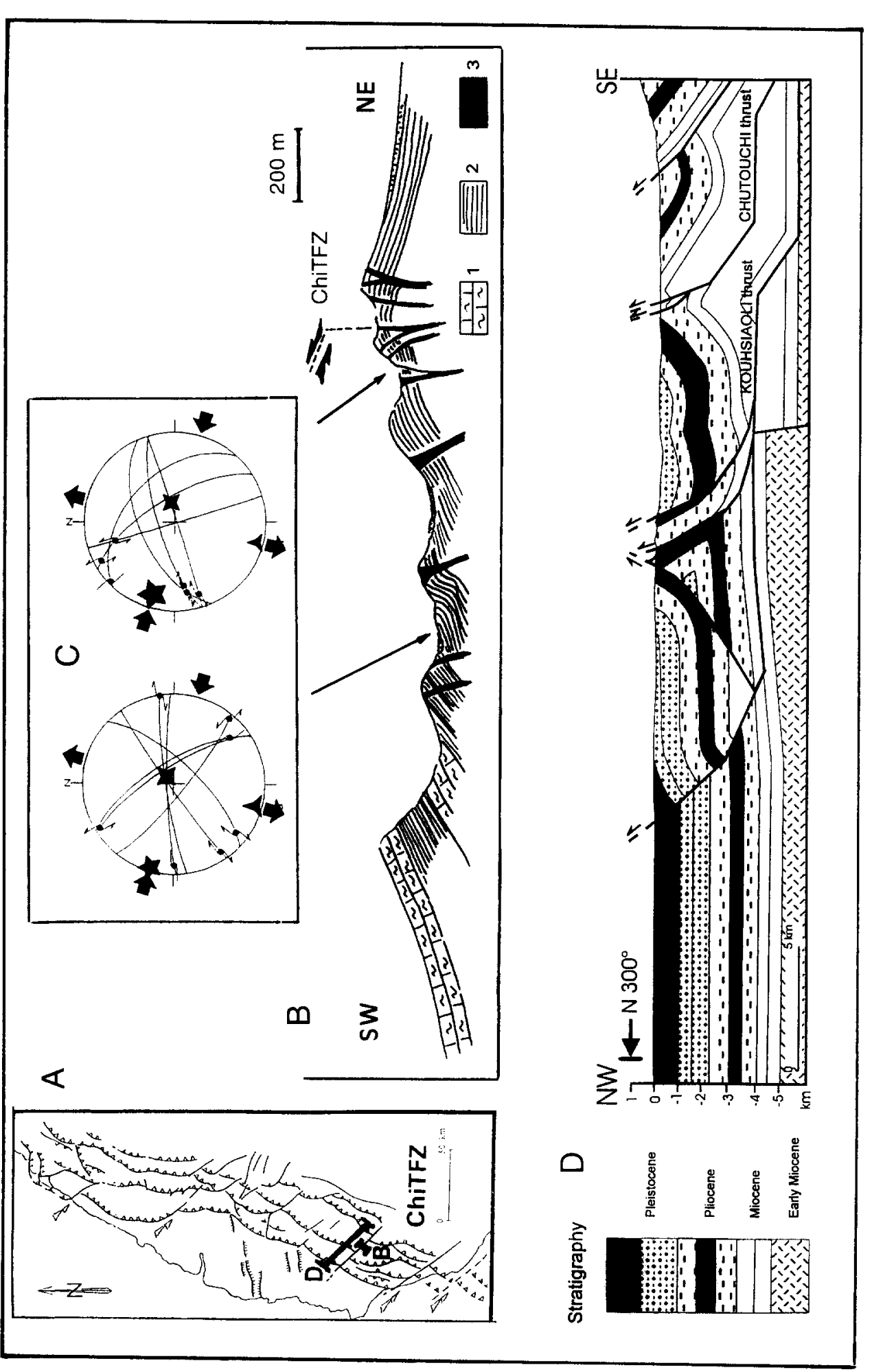

$\overline{3}$

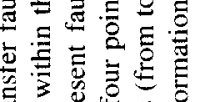
可

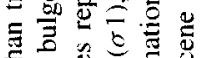

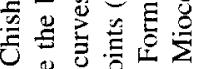

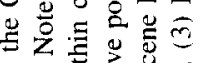

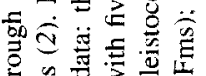

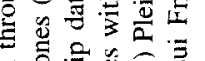
흥

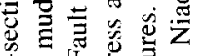
है 远记 三

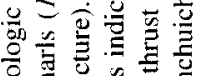

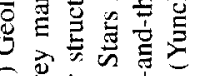
๙

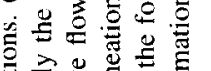

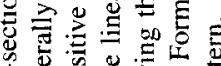

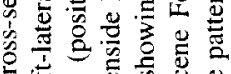

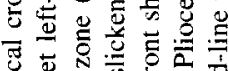

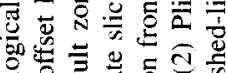

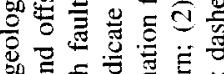

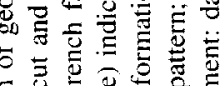

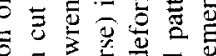
可

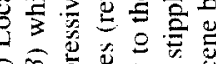

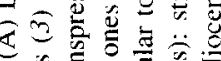

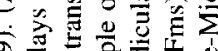
is

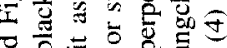

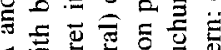

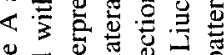

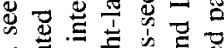
동

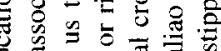

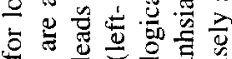

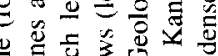

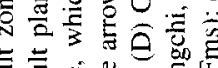

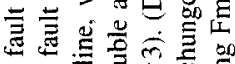

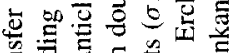

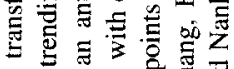

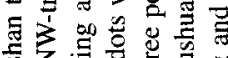

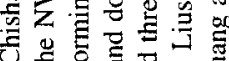

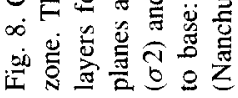




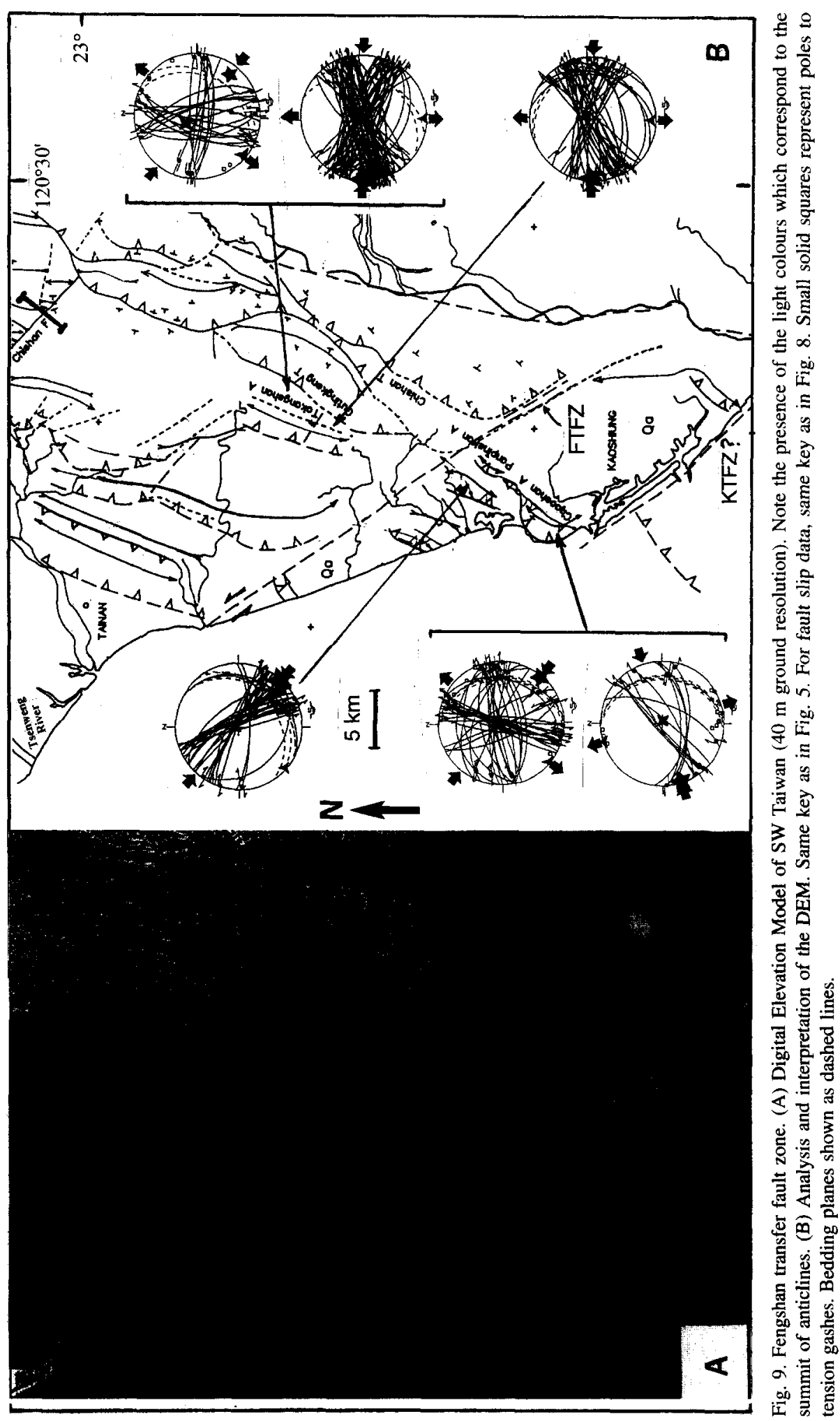


The Takangshan and Hsiaokangshan reefs covering the Takangshan anticline are apparently offset with respect to the Panpingshan and Shaoshan reefs covering the Panpingshan anticline. The apparent offset reaches about $5-7 \mathrm{~km}$. These reefs are all of Pleistocene age (1.2 to 0.45 Ma based on nannoplankton data), but in detail they are younger from south (Shaoshan) to north (Takangshan: Chi, 1979; Chang and Chi, 1983; Gong et al., 1995). This slight but real diachronism of reefs (and hence probably of the anticlines on the top of which they developed) makes the discussion of the regional significance of the apparent offset of the reefs in terms of displacement along the fault zone difficult. However, considering the Panpingshan and the Hsiaokangshan reefs, which are located on both sides of the inferred fault zone and display a nearly similar age (1 Ma on average), one may determine a value of $6 \pm 1$ $\mathrm{mm} /$ year along the fault; this value only constitutes an upper limit for the actual displacement rate which cannot be determined rigorously.

\subsection{Kaohsiung transfer fault zone (KTFZ)}

South of the city Kaohsiung the rectilinear NW-SE-trending shape of the shoreline at Kaohsiung and the sigmoidal shape of the Shaoshan reef might be interpreted as due to a NW-SE fracture zone. Comparison with the above-mentioned criteria for identifying a transfer fault zone lead us to suspect a similar $\mathrm{N} 140^{\circ}$ transfer fault zone (Fig. 9B). Evidence remains poor, because of low relief and thick recent sediment infill, so that further subsurface investigation (as was done by Sun, 1963 near Kaohsiung) is needed to precisely characterize the inferred Kaohsiung transfer fault zone.

\section{Discussion}

Several aspects dealing with the presence of the oblique major morphostructures need now to be addressed. (1) Do these fault zones correspond to strike-slip faults or to transfer faults? (2) Are they newly formed (hereafter neoformation) in the cover strata or do they result from reactivation of basement structures? (3) Are they still active today? (4) What is their significance in relation to the geodynamic setting and the present-day stress field?

\subsection{Strike-slip or transfer fault zones?}

The interpretation of the $\mathrm{N} 140^{\circ} \mathrm{E}$-trending structures as transfer fault zones is based on the identification of parts of thrust sheets having different displacement on both sides of the fault. The sigmoidal shape of thrusts and fold axes, the mismatches of compressional features on both sides of the fault zone (disappearance, change of dip direction) and the different senses and rates of displacement between two adjacent blocks suggest that faulting occurred during (rather than after) fold and thrust development, and therefore argue in favour of transfer faulting (Fig. 10). As Table 1 shows, these transfer fault zones may connect structures of various types and with various vergences: fold/fold, thrust/thrust, thrust/back-thrust. For instance, the CTFZ is of thrust/thrust type. The PTFZ is clearly associated with fold development (fold/fold type tranfer fault zone), especially in its northern part. To the south, the Pakuashan anticline shows a asymmetric structure (fault-propagation fold, Delcaillau et al., 1993) whereas it appears symmetric to the north on top of the PTFZ (fault-bend fold or incipient fault-propagation fold or symmetric positive flower structure). The linearity of the flanks of the Pakuashan anticline can be interpreted as the emergence of the deformation front to the southwest and of a back-thrust to the northeast (SPOT-P, Fig. 6A), so that in the north the PTFZ is rather of the thrust/back-thrust type (Table 1). It should be noticed that our attempt at classifying transfer fault zone structures (Table 1) has somewhat arbitrary aspects, because most of the fold structures in the Taiwan Foothills are related to thrust development (e.g., Suppe and Namson, 1979; Suppe, 1980).

Differences in the morphologic and structural signatures of these fault zones suggest that the actual mechanism of faulting may also vary: transpressive, pure strike-slip or transtensive (Table 1). As an example, evidence of transpressive deformation is provided by the bulge of the layers which form a kind of pressure ridge parallel to the transfer fault zone: this is well evidenced in the case of the ChiTFZ. In contrast, the transtensive component is marked in the field by normal faulting in different directions (e.g., the PTFZ: Fig. 6).

We would like to point out that as a consequence of the transfer character of the fault zones inves- 


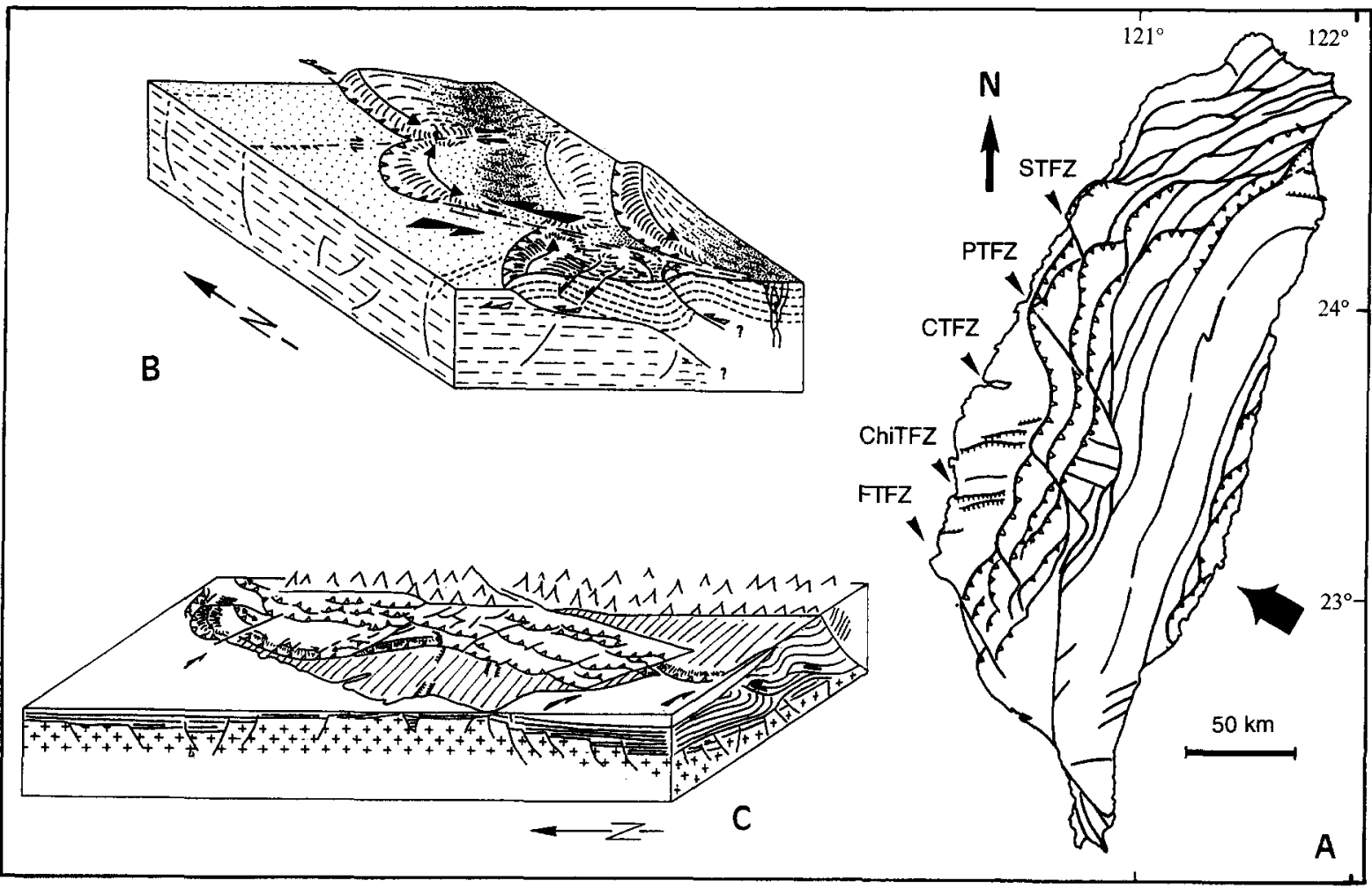

Fig. 10. Final structural interpretation of the Taiwan Foothills. (A) Updated structural map of Taiwan. Note especially the location of the different transfer fault zone and the geometry of the Foothills (the black arrow corresponds to the present Philippine Sea Plate convergence). (B) Schematic synthetic 3-D view of a typical left-lateral transfer fault zone and associated right-lateral strike-slip fault as evidenced in the Taiwan Foothills. (C) 3-D schematic view of the Taiwan Coastal Plain and Foothills.

Table 1

Descriptive classification of transfer fault zones in the Western Taiwan Foothills

\begin{tabular}{|c|c|c|c|c|}
\hline \multirow[t]{2}{*}{ Type } & \multirow[t]{2}{*}{ Mechanism } & \multicolumn{2}{|c|}{ Present-day activity } & \multirow[t]{2}{*}{ Examples } \\
\hline & & GPS & seismicity & \\
\hline \multirow[t]{3}{*}{ Fold-fold transfer fault } & Pure strike-slip & & & \\
\hline & Transtensive-normal component & $?$ & $?$ & Pakua (South) \\
\hline & Transpressive-reverse component & GPS mut, & num. focal mech & Chishan \\
\hline \multirow[t]{3}{*}{ Thrust-thrust transfer fault } & Pure strike-slip & few GPS mvt, & num. focal mech & Sanyi \\
\hline & Transtensive-normal component & GPS mut, & few focal mech & Fengshan \\
\hline & Transpressive-reverse component & $?$ & $?$ & Chiayi \\
\hline \multirow[t]{3}{*}{ Thrust-back thrust transfer fault } & Pure strike-slip & & & \\
\hline & Transtensive-normal component & $?$ & $?$ & Pakua (North) \\
\hline & Transpressive-reverse component & & & \\
\hline
\end{tabular}

tigated, displacement rates estimates based on the differential motion along them must be considered with care. First, the apparent offset of thrust fronts may differ from the initial mechanism. Differential erosion following or accompanying thrust emplacement may have resulted in an apparent offset that 
differs markedly from the initial offset. Second, because only the differential displacement (i.e., based on the offset of passive markers) can be determined as for strike-slip faults, estimating the displacement rate based on the offset of such markers on both sides of a transfer fault may lead to underestimation of the total rate of displacement of thrust units.

\subsection{Reactivation of basement structures or neoformation?}

The N $140^{\circ}$ E-trending transfer fault zones connecting the thrust sheets in the Western Foothills may have initiated in the cover strata in response to compressional thin-skinned tectonics or may result from an overprint in the overlying sedimentary cover of reactivated basement features.

Most of the extensional features related to the Miocene extension and rifting of the passive Chinese margin are oriented E-W and ENE-WSW (Ho, 1986a,b). Closely spaced CPC seismic profiles offshore Tainan (Yang et al., 1991) effectively evidenced many E-W normal faults, sometimes in enéchelon patterns, connected by nearly $\mathrm{N}-\mathrm{S}$ transfer faults with strike-slip character (Yang et al., 1991). Palaeostress reconstructions in the Penghu Islands additionally suggest that these extensional features are related to a Middle-Late Miocene $\mathrm{N}-\mathrm{S}$ extension followed by a Late Miocene NW-SE extension. inducing complex patterns of normal faults associated with NNW-SSE transfer faults nearly parallel to the extension (Angelier et al., 1990). These N-S to NNW-SSE faults constitute weakness zones in the basement available for reactivation, which could have induced and guided the development of transfer fault zones in the overlying cover during the Quaternary thrust tectonics. This is probably the case for the STFZ, which constitutes the present-day seismic northern boundary of the Peikang High (Fig. 4A), but also for the PTFZ which extends at depth below the décollement level above which folds and thrusts developed (CPC, unpublished data).

However, the very little evidence of N $140^{\circ} \mathrm{E}-$ trending fault zones in the Miocene basement (Letouzey et al., 1987) leads us to propose that most $\mathrm{N} 140^{\circ} \mathrm{E}$ transfer fault zone observed throughout the Foothills were not systematically guided and localized by underlying inherited basement discontinuities, but rather newly formed within the cover above the décollement level(s) of the Neogene sedimentary series of the Foothills: they consequently developed parallel to the transport direction in response to local mismatches during thrust emplacement, and root at depth within the décollement levels where mechanical decoupling occurs. Note that depending on the thickness of the sedimentary series and/or the palaeogeography, the décollement level may vary in age and depth. As an example, transfer fault zones are likely to root at depth within the Upper Oligocene-Miocene Wuchihshan formation or the Pliocene Cholan formation in the Pakua area, in the Miocene Nankang and/or Nanchuang formations in the Chiayi area, or the equivalent of the Nankang formation in the Kaohsiung area (Mouthereau, 1995).

\subsection{Consistency of transfer fault kinematics with Quaternary and present-day stress fields}

The transfer fault zones basically trend parallel to the direction of thrust motion, and more generally, parallel to the direction of displacement of tectonic units. The $\mathrm{N} 140^{\circ} \mathrm{E}$ direction thus corresponds to the Quaternary regional direction of emplacement of tectonic units at the scale of the orogen (Fig. 10), slightly oblique to the direction of the relative convergence (N300-305). These $\mathrm{N} 140^{\circ} \mathrm{E}$ transfer fault zones mainly accommodate the differential westward motion of thrust sheets due to the blocking of the propagating thrust units by structural highs within the basement (the Peikang and Kuanyin highs: see Fig. 1). As an example, the $\mathrm{N} 140^{\circ} \mathrm{E}$ left-lateral Pakua transfer fault zone probably accommodated the blocking of thrust propagation by the Peikang High to the south, whereas the northern part remained relatively free to propagate westwards (Fig. 6B). The development of a transfer fault zone generally results from the local mechanical accommodation of kinematic incompatibilities, such as differential thrust motions or thrust propagation rates. The sense of shear is usually (but not always easily) derived from the offset of various markers, such as for lithological markers or initially aligned fold axes.

A striking point concerning the $\mathrm{N} 140^{\circ}$ transfer fault zones of the Western Foothills is that all of 
them exhibit evidence of left-lateral sense of shear (Fig. 10). This suggests that the motion along these faults is generally consistent with the regional stress field. The compressional trends during Pleistocene times, which were $\mathrm{N} 105^{\circ}$ on average (Angelier et al., 1986; Chu, 1990), should effectively induce a left-lateral shear on $\mathrm{N} 140^{\circ}$-trending fault zones.

Considering that the $\mathrm{N} 140^{\circ}$ fault zones correspond to transfer fault zones and not to simple transcurrentwrench faults oblique to the Taiwan fold-and-thrust belt, the significance of the second family of oblique features, i.e., the $\mathrm{N} 80^{\circ} \mathrm{E}$ - to $\mathrm{N} 100^{\circ} \mathrm{E}$-trending faults, has to be discussed. Because of the number and the large extent of $\mathrm{N} 140^{\circ}$ faults, they very probably correspond to major structures guiding the thrust propagation in the cover (Fig. 10). The nearly E-W faults offsetting thrusts in the Foothills show very little or no evidence of transfer motion, and may simply correspond to dextral strike-slip faults acting as conjugate shears with respect to the left-lateral $\mathrm{N} 140^{\circ}$ fault zones, in agreement with the $\mathrm{N} 105^{\circ}$ regional compression. Seismic and geological studies support the dextral reactivation of the $\mathrm{E}-\mathrm{W}$ normal faults of the margin into right-lateral strike-slip faults (Fig. 10B). As an example, the dextral offset of the orbitoid limestone along the southern boundary of the Peikang High provides evidence for such a reactivation (Tang, 1977).

The orientations and the motion senses of the transverse faults in the Chiayi region are more complex (Fig. 7) and need further discussion. In this area, we have characterized a $\mathrm{N} 110^{\circ}$ transfer fault zone, based on the lateral displacements of the apparent deformation front, the differential location of the frontal deposits, the virgation of the Chukou thrust fault and the offset of the anticline axes (see previous sections). However, N100-110 -trending faults offsetting thrusts and anticline axes in the more internal part of the belt have been previously interpreted as transfer fault zones (Ho, 1986a,b). Fig. 7 shows that some of them display right-lateral motion, whereas some others exhibit a left-lateral one, in agreement with the sense of motion evidenced from our study. These apparently inconsistent senses of motion along $\mathrm{N} 110^{\circ}$-trending faults should be explained in terms of local variations in fault orientation and in regional stress trends. The Quaternary $\mathrm{N} 100-110^{\circ}$ compression is nearly parallel to the direction of thrust mo- tion, so that along the transfer fault zone right-lateral as well as left-lateral strike-slip movements may be expected, depending on local kinematic accommodation of thrust propagation.

\subsection{Present-day activity}

The previously described fault zones (Sanyi, Pakua, Chiayi, Chishan and Fengshan) acted as transfer fault zones during the Quaternary. Several criteria can be used to determine whether or not such faults are still active at the present day. The markers of such a present-day activity may correspond to the seismic activity or the differential displacement velocities deduced from GPS data on hoth parts of the fault zones (Yu and Chen, 1992; Yu and Kuo, 1993).

We have already noticed the important seismic activity of the Sanyi and the Chishan N140 fault zones which appear as major seismic boundaries and are thus still tectonically active (Fig. 4A). The lack of seismicity within the PTFZ may indicate that this fault zone is no longer active.

In contrast to the Northern Foothills where uncertainties on the results are too large to draw definite conclusions for the Sanyi and Pakua fault zones, GPS data in the Western Foothills (Yu and Chen, 1992; Yu and Kuo, 1993, 1994) provide additional evidence of the present-day left-lateral transfer motion along the Chiayi, Chishan and Fengshan faults (Fig. 11A). For these faults, we determined the component of displacement velocities of stations located on both sides of the fault zone along the direction of the fault zone (Fig. 11B). For the Chiayi fault, the NE block is found to move westward at a rate of about $33 \mathrm{~mm} / \mathrm{y}$, whereas the SW block is moving westward at a rate of about $26 \mathrm{~mm} / \mathrm{y}$, suggesting a left-lateral motion along the fault; for the Chishan fault, the NE block is moving westward at a rate of about $18.5 \mathrm{~mm} / \mathrm{y}$, whereas the SW block is moving westward at a rate of about $7.5 \mathrm{~mm} / \mathrm{y}$, also suggesting a left-lateral motion along the fault; finally, for the Fengshan fault, the NE block is moving westward at a rate of about $13 \mathrm{~mm} / \mathrm{y}$, whereas the $S W$ block is moving westward at a rate of about $7.5 \mathrm{~mm} / \mathrm{y}$. This confirms that the Chiayi, Chishan and Fengshan faults are probably still active left-lateral transfer fault zones accommodating the westward differential motion of thrust units on both sides of them. 


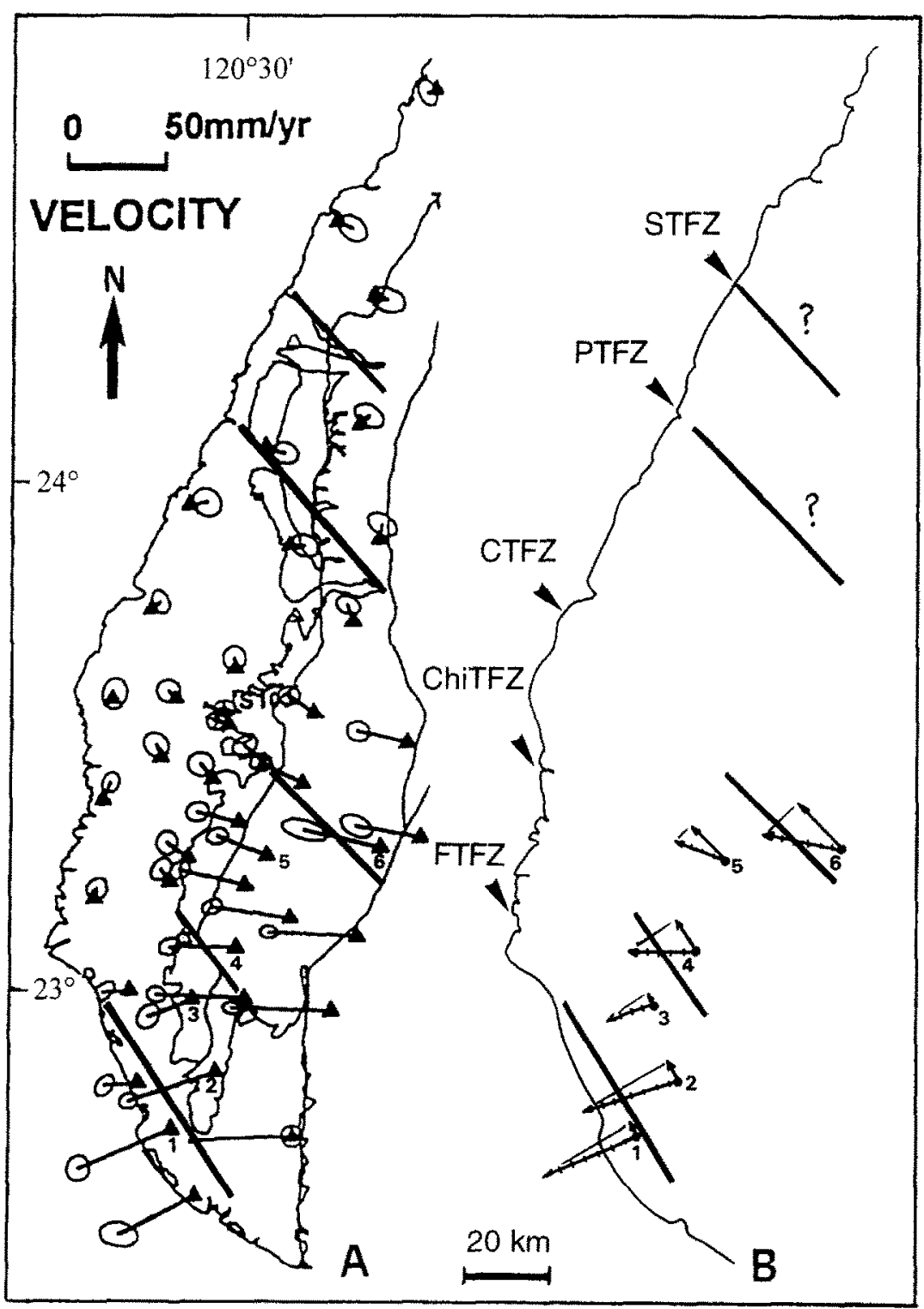

Fig. 11. Present-day activity of the Taiwan Foothills transfer fault zones. (A) GPS network and velocity field of stations in the Western Foothills of Taiwan, adapted from Yu and Chen (1992) and $Y u$ and Kuo $(1993,1994)$. Black triangles are annually surveyed GPS stations, while the triangles inside circles are continuous monitoring permanent stations. Station velocities are relative to the Penghu Islands. The $95 \%$ confidence ellipse is shown at the tip of each velocity vector. Heavy lines: transfer fault zones. (B) Principle of determination of the present-day left-lateral motion along the Chiayi, Chishan and Fengshan transfer fault zones. by taking into account the components of velocity vectors parallel to the fault trend of stations located on both sides of the faults.

\section{Conclusion}

This work not only confirms the presence of N140 major structures oblique to the Taiwan fold-and-thrust belt deformation front but also allows identification of their tectonic behaviour, as transfer fault zones consistent with the northwestward motion of the fold-and-thrust belt front (Fig. 10). These NWtrending morphostructures are interpreted as various types of transfer fault zones acting during the Quater- 
nary (Table 1). Their present-day tectonic activity is supported by the high seismic activity of both STFZ and ChiTFZ, and the present displacement derived from the GPS data also supports this conclusion in terms of active transfer faulting (e.g. Chiayi, Chishan and Fengshan transfer fault zones). The origin of these fault zones, however, deserves further investigations because the origin of weakness zones often remains unclear (inherited structures of the Eurasian passive margin reactivated during the last collision or neoformed fault zones during this collision). An important practical consequence of this study lies in the integration of the data newly collected within a Geographical Information System database. These will allow improvement of the geological mapping in areas which are characterized by abundant tropical vegetation and high precipitation. The identification of several left-lateral transfer fault zones, which trend $\mathrm{N} 140^{\circ}$ and obliquely cut the NNE-trending folds and thrust units of the outer (westernmost) fold-and-thrust belt, allows better understanding of the structure and the deformation modes of the Western Foothills of the Taiwan collision belt.

\section{Acknowledgements}

This research has been done with various supports from the Taiwan-France cooperation program supported by the French Institute in Taipei (IFT) and the National Science Council (NSC), the Central Geological Survey of Taiwan, the Pierre et Marie Curie University, the National Taiwan University, the French Programme National de Télédétection Spatiale (PNTS), the C.R.O.U.S., and the Ministry of Education of Taiwan. Most figures are due to the computing skills of J.F. Brouillet and J.Carvalho. SPOT images have been printed by $M$. Danrée and M. Moroni. The authors would also like to thank Dr O. Bellier and Dr T.-Y. Lee for their constructive comments on the manuscript.

\section{References}

Angelier, J., 1990. Inversion of field data in fault tectonics to obtain the regional stress, III, A new rapid direct inversion method by analytical means, Geophys. J. Int., 103: 363-376.

Angelier, J., Barrier, E. and Chu, H.T., 1986. Plate collision and paleostress trajectories in a fold-thrust belt: the Foothills of Taiwan. Tectonophysics, 125: 161-178.
Angelier, J., Bergerat F. and Chu, H.T., 1990. Paleostress as a key to margin extension: the Penghu Islands, South China Sea. Tectonophysics, 183: 161-176.

Barrier, E., 1985. Tectonique d'une chaîne active: Taiwan. Thése d'Etat, Université P. et M. Curie, Paris, 492 pp.

Biq, C., 1989. The Yushan-Hsueshan megashear zone in Taiwan. Proc. Geol. Soc. China, 32: 7-20.é

Carvalho, J., 1995. Extraction automatique d'informations géomorphométriques (Réseaux et surfaces enveloppes) à partir de modèles numériques de terrain. Thése de Doctorat-ésSciences, Université P. et M. Curie, Paris, 172 pp.

Chang, S.S.L. and Chi, W.R., 1983. Neogene nannoplankton biostratigraphy in Taiwan and the tectonic implications. Pet. Geol. Taiwan, 19: 93-147.

Chi, W.R., 1979. A biostratigraphic study of the Late Neogene sediments in the Kaohsiung area based on calcareous nannofossils. Proc. Geol. Soc. China, 22: 121-144.

Chu, H.T., 1990. Néotectonique cassante et collision plio-quaternaire à Taiwan. Thése de Doctorat-és-Sciences, Université Pierre et Marie Curie, Paris, 292 pp.

CPC, 1974.Geological Map of Taiwan, 1:100,000, 3, Miaoli.

CPC, 1982. Geological Map of Taiwan, $1: 100,000$, 4, Taichung.

Deffontaines, B. and Chorowicz, J., 1991. Principle of drainage basin analysis from multisource data. Application to the structural analysis of the Zaire Basin. Tectonophysics, 194: 237263.

Deffontaines, B., Chotin, P., Ait Brahim, L. and Rozanov, M., 1992. Investigation of active faults in Morocco using morphometric methods and drainage pattern analysis. Geol. Rundsch., 81: 199-210.

Deffontaines, B. Lee, J.C., Angelier, J., Carvalho, J. and Rudant, J.P., 1994. New morphoneotectonic data in Taiwan: analyses of digital elevation model, SPOT and Radar images, and geodynamic implications. J. Geophys. Res., 99, B10: 20,243-20,266.

Delcaillau, B., Angelier, J. Herail, G., Chu, H.T., Lee, J.C., Liew, P.M., Lin, T.S., Lu, C.Y., Teng, L., Deramond, J. and Souquet, P., 1993. Evolution morphostructurale et sédimentaire d'un bassin d'avant-pays en régime de collision oblique: le Piémont occidental de Taiwan. C.R. Acad. Sci., Paris, 315, Sér. II: 1239-11244.

Gong, S.Y., Lee, T.Y., Wu, J.C., Wang, S.W. and Yang, K.M., 1995. Possible links between Plio-Pleistocene reef development and thrust migration in the Southwestern Taiwan. Proc. ACT Symp., pp. 113-119.

Ho, C.S., 1967. Structural evolution and major tectonic forms of Taiwan. Proc. Geol. Soc. China, 10: 3-24.

Ho, C.S., 1979. Geologic and tectonic framework of Taiwan. Mem. Geol. Soc. China, 3: 57-72.

Ho, C.S., 1986a. Geological Map of Taiwan, 1:500,000. Centr. Geol. Surv., MOEA, Taipei.

Ho, C.S., 1986b. A synthesis of the geologic evolution of Taiwan. Tectonophysics, 125: 1-16.

Ho, C.S., 1988. An introduction to the geology of Taiwan, Explanatory text of the Geologic map of Taiwan, 2nd ed. Central Geological Survey, Taiwan, 192 pp.

Hobbs, W.H., 1904. Lineaments of the Atlantic border region. Geol. Soc. Am. Bull., 15: 483-506, 1904. 
Howard, A.D., 1967. Drainage analysis in geologic interpretation: a summation. Am. Assoc. Pet. Geol. Bull., 51: 22462259.

Hsu, T.L.. 1956. Geology of the Coast Range, eastern Taiwan. Bull. Geol. Surv. Taiwan, 8: 39-64.

Huang, S.T., Chen, R.C. and Chi, W.R., 1993. Inversion tectonics and evolution of the northern Taihsi basin. Taiwan. Pet. Geol. Taiwan. 28: 15-46.

Lacombe, O., Angelier, J. and Laurent, P., 1993a. Les macles de la calcite, marqueurs des compressions récentes dans un orogéne actif: l'exemple des calcaires récifaux du sud de Taiwan. C.R. Acad. Sci., Paris. 316: 1805-1813.

Lacombe, O., Angelier, J., Byrne. D. and Dupin, J.M.. 1993 b. Eocene-Oligocene tectonics and kinematics of the Rhine-. Saone continental transform zone (eastern France). Tectonics. 12(4): 874-888.

Lacombe, O., Angelier, J., Rocher, M.. Chen, H.W., Chu. H.T.. Deffontaines, B.. Hu. J.C. and Lee. J.C., 1995. Calcite twin analysis: a key to the recent stress fields at the front of the Taiwan Collision belt. Proc. ACT Symp., pp. 157-166.

Lacombe, O., Angelier, J., Chen, H.W., Deffontaines, B., Chu. H.T. and Rocher, M., 1997. Syndepositional tectonics and extension-compression relationships at the front of the Taiwan collision belt: a case study in the Pleistocene reefal limestones near Kaohsiung, SW Taiwan. In: S.E. Lallemand and H.-H. Tsien (Editors). Active Collision in Taiwan. Teclonophysics. XXX: (this issue).

Lee, J.C., 1994. Structure et déformation active d'un orogène: Taiwan. Mém. Sci. Terre Univ. P. et M. Curie, 94-X, 281 pp.

Lee, T.Y.. Hsu. Y.Y.. Tang, C.H., 1995. Structural geometry of the deformation front between $22^{\circ} \mathrm{N}$ and $23^{\circ} \mathrm{N}$ and migration of the Penghu Canyon, offshore Southwestern Taiwan ArcContinent Collision Zone. Proc. ACT Symp., pp. 219-227.

Letouzey, J., Sage, L. and Muller, C.. 1987. Geological and structural maps of eastern Asia. Notice Institut Français du Pétrole, Paris, 73 pp.

McClay, K.R., 1992. Glossary of thrust tectonic terms. In: K.R. McClay (Editor), Thrust Tectonics. Chapman and Hall. London, pp. 419-433.

Mouthereau, F., 1995. Géométrie et cinématique du front de chaine de Taiwan. Mém. DEA Université P. et M. Curie (unpublished), $63 \mathrm{pp}$.

Mouthereau, F., Angelier, J., Deffontaines, B., Lacombe, O., Chu. H.T., Colletta, B., Déramond, J., Yu. M.S. and Lee, J.F.. 1996. Cinématique actuelle et récente du front de chaîne de Taiwan. C.R. Acad. Sci., Paris, 323, II: 713-719.

MRSO, 1981. Taiwan SLAR images, $1: 250,000$, taken by Mars Aerial Remote Sensing. Inc.

O'Leary, D.W., Friedman, D. and Pohn, M.A., 1976. Lineament. linear, lineation: some proposed new standards for old terms. Geol. Soc. Am. Bull., 87: 1463-1469.

Pelletier, B. and Stephan. J.F., 1986. Middle Miocene obduction and late Miocene beginning of collision registered in the Hengchun peninsula: geodynamic implications for the evolution of Taiwan. Tectonophysics, 125: 133-160.

Scanvic, J.Y., 1983. Utilisation de la télédétection dans les sciences de la terre. Manuel et Méthodes. . Bureau de Recherches
Géologiques et Miniéres, Orléans, Vol. 7, 158 pp.

Shin, T.C. and Chang, Z.S., 1992. Earthquakes in 1992. Meteorol. Bull., Cent. Weather Bur., 38(3): 218-232

Sun, S.C. 1963. The reef limestones and the geologic structures in the vicinity of Kaohsiung City, Taiwan. Pet. Geol. Taiwan. 2: $47-64$.

Sun, S.C.. 1964. Photogeologic Study of the Tainan-Kaohsiung Coastal Plain Area. Taiwan. Pet. Geol. Taiwan, 3: 39-51.

Suppe. I., 1976. Decollement folding in southwestern Taiwan. Pet. Geol. Taiwan, 13: 25-36.

Suppe. J., 1980. Imbricated structure of Western Foothills belt, South-Central Taiwan. Pet. Geol. Taiwan, 17: 1-16.

Suppe, J.. 1981. Mechanics of mountain-building and metamorphism in Taiwan. Mem. Geol. Soc. China, 4: 67-90.

Suppe, J., 1984. Kinematics of arc-continent collision, flipping of subduction, and back-arc spreading near Taiwan. Mem. Geol. Soc. China, 4: 67-90.

Suppe, J. and Namson, J., 1979. Fault-bend origin of frontal folds of the Western Taiwan fold-and-thrust belt. Pet. Geol. Taiwan, 16:1-18.

Suppe. J., Hu, C.T. and Chen, Y.-J., 1985. Present-day stress directions in western Taiwan inferred from borehole elongation. Pet. Geol. Taiwan, 21: 1-12.

Tang, C.H., 1977. Late Miocene erosional unconformity on the subsurface Peikang high beneath the Chiayi-Yunlin coastal plain. Taiwan. Mem. Geol. Soc. China, 2: 155-167.

Teng. L.S. 1990. Geotectonic evolution of late Cenozoic arccontinent collision in Taiwan. Tectonophysics, 183: 57-76.

Xiahoan. L.. 1983. Perturbations de contraintes liées aux struclures cassantes dans les calcaires fins du Languedoc. Observations el simulations mathématiques. Unpublished Ph.D. thesis, Université des Sciences et Techniques du Languedoc, Montpellier, $152 \mathrm{pp}$.

Yang, K.M., Ting, H.H. and Yuan, J., 1991. Structural styles and tectonic modes of Neogene extensional tectonics in SW Taiwan: implications for hydrocarbon exploration. Pet. Geol. Taiwan, 26: $|-3|$.

Yeh. M.G. and Yang. C.Y., 1992. Notes on the characteristics of the Fangliao fault in the Kaohsiung area, Taiwan. Pet. Geol. Taiwan. 27: 217-224

Yeh. Y.H.. Barrier, E. and Angelier, J., 1991. Stress tensor analysis in the Taiwan area from focal mechanisms of earthquakes. Tectonophysics, 200: 267-280.

Yu. S.B. and Chen. H.Y., 1992. A global positioning system network for crustal deformation study in Taiwan. Bull. Inst. Earth Sci. Acad. Sin., pp. 52-55.

Yu. S.B. and Kuo, L.C., 1993. Utilizing continuous GPS data for study the crustal deformation in Taiwan. Bull. Inst. Earth Sci. Acad. Sin., 13:77-82.

Yu. S.B. and Kuo, L.C.. 1994. Utilizing continuous GPS observed data to study the crustal deformation in Taiwan (abstr.). Annu. Meet. Geol. Soc. China.

Zoback, M.D., Zoback, M.L., Mount, V.S., Suppe, J., Eaton, J.P., Healy, J.H., Oppenheimer, D., Reasenberg, P., Jones, L.. Raileigh, C.B., Wong, I.G., Scotti, O. and Wentworth, C.. 1987. New evidence on the state of stress of San Andreas fault system. Science. 238: 1105-1111. 